\title{
The Gypsy's Curse: Race and Impurity of Blood in Pardo Bazán
}

En el presente ensayo se estudia el estereotipo de la gitana en tres obras de Emilia Pardo Bazán y lo que revela sobre la cuestión de raza en la España de fin de siglo. En Insolación (I889) el proceso de estereotipar a la gitana y al andaluz sirve, paradójicamente, tanto para celebrar la otredad exótica de los españoles como para contener la amenaza del Otro racial dentro de la sociedad española. En dos cuentos más tardíos se complica el asunto racial haciéndose más borrosa la división entre gitanos y payos, orientalizando a todos los españoles, y revelando un contexto en el cual la violencia del patriarcado y del racismo compite con el salvajismo del Otro. En "Maldición gitana" (I897) la diferencia racial es el motivo implícito de un fratricidio supuestamente causado por la maldición de una gitana. En "La novela de Raimundo" (I898) un narrador masculino, indigno de confianza, revela, sin darse cuenta, su papel en el asesinato de una gitana por su propia tribu. Mientras que estos dos cuentos presentan estereotipos negativos de la gitana, al mismo tiempo, los narradores cuentan otra historia, a pesar de sus intenciones. En ambos casos se trata de relatos de violencia física, verbal y psicológica contra el Otro racial y sexual.

In the mid nineteenth century a revival of interest in Roma culture contributed to the conversion of the Spanish gypsy into a romantic symbol of nonconformity, passion, racial purity, and nature. This trend also coincided with Europe's fascination, and "invention," to use Edward Said's words, of the Orient, making Andalusia and gypsy culture especially attractive to foreigners (Said 5; Charnon-Deutsch 59). These romantic portrayals, however, also betrayed ambivalence towards the gypsies whose alleged poverty, filthiness, salaciousness, and proclivity for trickery, theft, hoarding, and incest, were also underscored. Indeed, at the same time that romantic artists were celebrating the gypsy's intransigent defiance of bourgeois modernity, physical anthropologists were affirming the hereditary nature of the gypsies' degeneracy (Charnon-Deutsch 13). Thus, the gypsy was being both admired and despised, this ambivalence being an integral dynamic, as we shall see, of the racial stereotype.

Spain's own relation to the gypsies was especially complex. Nineteenth-century Spaniards' desire to assert a unique national identity to counter French and English cultural hegemony led many to promote a 
Spain whose essence was to be found among the behaviors and traditions of marginalized groups such as gypsies (Dorca II4; Cantos Casenave 66, Torrecilla $4^{-6}$ ). At the same time, foreigners themselves were turning to Andalusia and gypsy culture, as a representation of the "real" Spain (Fernández Cifuentes I36). In a context in which authentic Spanishness was contraposed to all things European, Andalusia, with its strong Moorish influences, proximity to Africa, and gypsies, seemed to make Spain most distinct from its European neighbors (137). Moreover, it was at this time that certain Spanish anthropologists were celebrating Spain's racial hybridity as an asset that gave them a racial advantage over other Europeans (Goode 75). Yet, not only did many Spaniards resist the idea of contrasting a racially mixed Spain to a racially pure Northern Europe, scientific theories on race were simultaneously serving to maintain social hierarchies based on racial difference within Spanish society (I4). Thus, on the one hand, there was a cultural desire to embrace Andalusian culture as authentically and uniquely Spanish, while on the other, a desire to distance oneself from gypsies and Spain's Moorish past.

Pardo Bazán, a product of her time, shared the belief that the most authentic representations of the Spanish character were to be found among the lower classes. In "La mujer española" (I890), published only a year after Insolación, she states that the best representation of the essence of the Spanish temperament, or any nation's temperament for that matter, is to be found among the pueblo, and especially among its women (Io8). This belief that female members of the lower classes best represent a nation's authentic, autochthonous culture serves as an example of what Lou Charnon-Deutsch cites as the frequent collapse of gender and race in the figure of the female gypsy, a dynamic that has the reciprocal effect of feminizing the racial Other, and racializing woman in order to underscore her "ontological identification with the destructive forces of nature" (240). The costumbrista sketches portrayed by Pardo Bazán in the merendero scenes in Insolación (I889), examined in detail below, reveal a reenactment of the racial stereotype as both an authentic representation of Spanish culture and as a racialized Other, as well as the conflation of race and gender in the figure of the gitanilla and the gypsy fortuneteller. Moreover, while the upper-class Andalusian man's racial difference is also highlighted, it is neutralized by an emphasis on racial hybridity, a trait being celebrated by Spanish anthropologists at the time. Two of Pardo Bazán's later stories, however, complicate the racial issue by further blurring the divisions between gypsies and payos, by Orientalizing all Spaniards, and by revealing a context in which the violence of patriarchy and racism competes with that of the savagery of the racial Other. In 
"Maldición gitana" (1897) racial difference is an implied motive in the murder of one brother by the other, a murder that is blamed on a gypsy's curse. In "La novela de Raimundo" (I898) an unreliable male narrator recounts his own unwitting role in the murder of a young gypsy woman by her own tribe. While both short stories make liberal use of unfavorable racial stereotypes of the gitana, the implied author has her male narrators tell another story in spite of their intentions: a story of physical, verbal, and psychological violence against a constructed racial and sexual Other, a story that can only be fully understood in relation to the texts with which it implicitly dialogues, namely the Biblical story of Cain and Abel, and Prosper Mérimée's Carmen, respectively.

Before examining the narrative portrayal of gypsy women in these three works by Emilia Pardo Bazán it is necessary to comment upon the role of the Other in the formation of the self. Any individual's relationship to the Other is complex since difference is always threatening in that it does not affirm who one is, or at least, who one wishes to perceive $\mathrm{him} /$ herself to be. Yet, at the same time, a sense of self is dependent upon a distinction from the Other since one is defined precisely in terms of what one is not. Thus, in order to integrate that necessary yet threatening difference, the ego attempts to fix and hierarchize difference, usually by portraying the Other as inferior or "bad," which is in itself an act of domination and aggression. Nevertheless, paradoxically, an understanding of the "bad" Other, requires an acknowledgment of sameness: we can only know and understand what we have experienced in ourselves. Thus, as explained by Sander Gilman, defining the Other becomes an act of psychological projection in which undesirable qualities that we refuse to recognize in ourselves are projected onto the Other ( 17 ). The Other, as an embodiment of the repressed elements of the self, promises integration and wholeness in that it represents the missing elements of the self, at the same time that it supports the illusion of absolute difference between self and Other that keeps intact the conscious yet divided self (I8). However, while the ego seeks to occupy the dominant side of the self/Other and good/bad binary pairs, it is not a stable relationship and sometimes the binary is inverted and the Other occupies the privileged position (I8). This can partly account for the ambivalence Homi Bhabha cites as an essential dynamic of the racial stereotype, which simultaneously produces attraction/fear, desire/aversion, and pleasure/pain in equal measures (67; 72). Thus, stereotyping is a psychological defense mechanism that is inherently plagued with contradictions since the integrity of self is both threatened by, and yet dependent upon, the difference the Other is made to embody, a difference that exists, but is repressed, in oneself. 
According to Bhahba, stereotyping is a process in which difference is first acknowledged, then fixed, and finally hierarchized as inferior (73). Since the Other's identity, or one's own identity for that matter, cannot truly be known, the stereotype attempts to reduce the racial Other to a set of "particular features that come, metonymically, to be emphasized over and above the diverse qualities of the object as a whole" (Hook 26). This concept of fixity, ${ }^{\mathrm{I}}$ which is similar to Sander Gilman's concept of "an image of control," is pivotal to Bhabha's conception of the stereotype because it is the means by which the dominant subject attempts to gain mastery over a threatening difference (Bhabha 66; Gilman 27). Nevertheless, the fact that the stereotype must be anxiously repeated shows that the Other always ultimately escapes its reach (Bhabha 66; 74-75). Thus, the relief obtained through the stereotype is only momentary, and, in fact, reproduces the initial anxiety from which one sought release, creating a never-ending spiral of repetition.

Also of importance to us here is the frequent collapse of the categories of race and gender. Gilman explains that, since two of the most primitive ways in which we understand ourselves are in terms of our sexual identity and our belonging to a particular group, race and gender are frequently conflated in questions of Otherness (23). Since white and male occupy the privileged terms in the white/black, male/female binary pairs, the racial Other is frequently feminized, just as the woman is frequently racialized. One example of this is Edward Said's assertion that the Orient was feminized in that the Oriental Other, like woman, was a creature of a Western "male power-fantasy," who was seen as intellectually inferior, passive, and willing to be dominated (205-06).

Emilia Pardo Bazán's Insolación is a good place to start exploring the contradictory dynamics of the stereotyping process as the novel simultaneously invokes the gypsy and the Oriental Other as representations of a supposedly authentic Spain and as embodiments of Asís's repressed, instinctual nature, at the same time that these figures are clearly differentiated from the upper-class and "racially pure" Asís. The psychological processes involved in the racial Othering of the gypsy women are seen in the merendero scenes in chapters five and six. First, a disheveled, sallow woman, with eyes like coal, wearing old, faded clothes and carrying a child in a shawl, appears at the entrance of the merendero and offers to read Asís's palm (59). After accepting a peseta and a glass of manzanilla, the bruja, as Asís refers to her, proceeds to tell Asís her fortune in a colloquial dialect difficult to understand (6o-6I). The racial differences between Asís and the gypsy fortuneteller are highlighted in the scene in which Asís observes the contrast between the smooth, white skin of her 
hand and the weathered, coppery skin of the gypsy woman's "garra" (606I). Shortly afterwards a gitanilla makes an appearance (67). She has dark skin, greasy black hair that is so dark it is almost blue (67). Her teeth and eyes shine because of the contrast with the darkness of her skin (67). Her forehead is flat like that of a snake, her greenish, skinny arms look like two reptiles, and her face brings the devil to mind: "una jeta que parecía la del mismo enemigo" (67). The reptilian imagery and satanic allusion shortly precede the terrible curse the gitanilla places on the waitress who chases her away $\left(67^{-68)}\right.$.

In an example of what Bhabha refers to as fixity, we are told of the gypsy women's dark skin, black hair, and bright eyes that shine intensely, as well as their association with snakes and the devil, all of which are clichés reproduced in previous stereotypical depictions of gypsies. ${ }^{2}$ The focus on skin is of particular importance as skin color has served as the primary visual marker of race, a sign that is simultaneously associated with pathology and sexual excess of the supposedly more primitive races (Bhabha 30; Gilman 25). After Pacheco takes note of the difference between Asís's hand and that of the gypsy, Asís herself tells us that:

En efecto, sin vanidad, tengo que reconocer que la mano de la gitana, al lado de la mía, parecía un pedazo de cecina feísmo: la tumbaga de plata, donde resplandecía una esmeralda falsa espantosa, contribuía a que resaltase el color cobrizo de la garra aquella, y claro está que mi diestra, que es algo chica, pulida y blanca, con anillos de perlas, zafiros y brillantes, contrastaba extrañamente (6o-6I)

Here the gypsy is not only dehumanized by the reference to her hand as a claw, but also by the reference to the coppery color of her skin which is compared to a piece of cured meat, all suggesting decay and illness, while Asís's own small, white, and smooth hand suggests youth, health and purity. Additionally the contrast between the gypsy's false emerald and Asís's authentic pearls, sapphires, and diamonds highlights the differences in social class. The attempt to draw a clear line between the "good" self and the "bad" Other, referring back to Gilman, is also seen in the demonization of the gypsies by the reference to the first gypsy fortuneteller as a witch, the description of the gitanilla in reptilian terms, and the comparison of her face to that of the devil himself (6r; 67).

Nevertheless the ambivalence the racial Other evokes can be seen in the fact that Asís simultaneously seeks distance from, yet contact with, the crowds at the fair. For example, she refuses to enter the church because she claims that such close proximity with the vulgar and smelly devotees at the shrine would have caused her to faint and die (5I) and later at home 
she literally tries to cleanse herself of all the "flamenquismo, barbaridad, [y] grosería" she mixed with at the fair (87), as if, as Noël Valis argues, she fears that her moral integrity has been threatened by contact with the marginal classes $\left(335^{-36}\right)$. Yet, at the same time, she enjoys her interactions with the gypsy fortuneteller - "me divierte lo que no es imaginable" (59) and claims that at the merendero she finds herself "más divertida que en un sainete" (64). Indeed Asís is drawn to people at the Feria for the same reason she is drawn to Pacheco, they embody the "savage" instinctual nature that is repressed within herself.

This returns us to the question of racial stereotyping as psychological projection. Asís is a character who has lived a repressed existence. At a young age Asís was forced to cut off relations with a young navy lieutenant and marry her uncle in order to acquire an aristocratic title. The Marquis was a much older man lacking in physical charms, making Asís view her marriage as a sacrifice (28). It also comes as no surprise that their marriage was devoid of "el delirio de los extremos amorosos, impropios de su edad y la de Asís combinadas" (84). Now, recently widowed, the 32-year old Asís finds her repressed libido coming to the fore in her contact with Pacheco who, as the Orientalized Other, embodies the sexual desire that has been repressed in herself. ${ }^{3}$ Here, it is necessary to note the way in which Pacheco, as an Andalusian man, is connected to the gypsies. According to Edward Said, until the nineteenth century the Orient referred to India and the Bible lands, but with the rise of British and French Imperialism it included more territories in North Africa and the Middle East (4). Thus, by all definitions at the time, Jews, Arabs, and gypsies were Oriental, gypsies either due to their supposed Egyptian origins (a fact that was being disproven linguistically, but still upheld in the Spanish cultural imaginary) or because of their Indian origins. ${ }^{4}$ As the supposed descendants of Egyptians (in the first two Pardo Bazán works studied here the gypsies are referred to as Egyptians), gypsies were racially tied to other Andalusians because of both geography and their supposed Arabic blood. ${ }^{5}$ Thus, although historically inaccurate, gypsies and Andalusians shared a racial heritage in the Spanish cultural imaginary.

Asís's Galician roots, on the other hand, spare her from the contaminating influence of Semitic blood. Indeed the members of the nineteenth-century Galician Regionalista movement defined Galicia's unique character not only in linguistic and geographical terms, but also in terms of race. The Regionalistas stressed their Celtic lineage and argued they were primarily an Aryan race, in contrast to the rest of the Peninsula, which was predominantly Semitic (Martin Márquez 46; Pereira-Muro 70). Even Pardo Bazán, who parted with the Regionalistas in her affirmation of 
"the concept of Spanish national unity," still distinguished "the 'Celtic' Galicians and Asturians from ... the 'African or Semitic' Andalusians and residents of Madrid" (Martín Márquez 46). ${ }^{6}$ Moreover, Joshua Goode claims that while most nineteenth-century Spanish anthropologists saw Spain's racial fusion as a primarily positive attribute, some such as Manuel Antón also felt that Spain's Arabic influence "occasionally left potentially negative legacies" that could account for some of Spain's current problems (cit. in Goode 73-74). Such assertions more closely resemble Spain's Early Modern discourses on purity of blood than a nineteenth-century espousal of racial hybridity. Thus, Galicia, as one of the regions least affected by the Moorish occupation of the Iberian Peninsula, represents a sort of pure Europeanness, in contrast to Andalusia, which is the most influenced by Spain's Moorish past.

The attempt to differentiate Asís from the Oriental Other is seen in the tertulia scene when Gabriel Pardo asserts that Asís, who was born in "el Noroeste, donde las mujeres son reposadas, dulces y cariñosas, sería capaz, al darle un rayo de sol en la mollera, de las mismas atrocidades que cualquier hija del barrio de Triana o del Avapiés..." (36). Invoking theories that associate racial temperament to the sun (Charnon-Deutsch 46), Gabriel Pardo argues that the sun could turn a Galician woman's inherited calm and loving disposition into the lusty savagery of the Oriental types associated with Triana (a working-class neighborhood in Seville populated with many gypsies) or Lavapiés (a poor ethnic neighborhood in Madrid that used to be the Jewish barrio). Gabriel Pardo's assertion is noteworthy in that it makes racial distinctions at the same time that it blurs them: Asís is racially different from the Oriental/Semitic Other who populates the Triana and Lavapiés neighborhoods, but with mere exposure to the sun, she becomes one of them. Race is again tied to Asís's character, specifically her emotional restraint when the hetero- and extradiegetic narrator tells us that "Entre las condiciones de carácter de la marquesa viuda de Andrade, y de los gallegos en general, se cuenta cierto don de encerrar bajo llave toda impresión fuerte. Esto se llama guardarse las cosas" (I46). Thus, Asís's serene temperament and emotional control points to repression and to her unconscious desire for psychic integration by interactions with the non-repressed racial and sexual Other.

Pacheco, an embodiment of the Spanish hybridity celebrated at the time, allows Asís to access the racial Other without as much fear of contamination. The aforementioned anthropologist Manuel Antón argued that Spaniards were a mix of a European race, the Libyan-Iberian race (with roots in North Africa), and the Syrian-Arab race (with roots in the eastern Mediterranean and Asia Minor) (cit. in Goode 7I), a mixture 
Pacheco seems to embody. While we are not privy to information about the dimensions of Pacheco's skull - one of the main ways such racial attributes were being determined -, we know that Asís admires Pacheco beauty precisely for the "mezcla de razas" that she sees in him, which are exhibited by the combination of his dark hair and tanned skin (like that of the gypsies) with a blonde mustache and blue eyes (like Northern Europeans) (47). Moreover, returning to the question of skin as the principal marker of race, in the scene at the merendero with the gypsy fortuneteller Asís notes that while Pacheco looks extra dark she immediately corrects her comment by saying that he looks especially "tan," and that she knows it is a "tan" because the skin under the collar of his shirt is fair: "parecía doblemente morena su tez, o mejor dicho, doblemente tostada, porque hacia la parte que ya cubre el cuello de la camisa se entreveía un cutis claro" (60). Thus, Pacheco is actually the prototype of the racial mixture that Spanish anthropologists were claiming was Spain's racial advantage over other European nations. Furthermore, Pacheco's respectability is enhanced by his gender (male) and upper-class status, while all the gypsy women in Insolación are only further marginalized by their gender and socio-economic class. Nevertheless, Gabriel Pardo prefers to stress the atavistic traits that tie Pacheco to the gypsies and Spain's Moorish past:

Ese andaluz es uno de los tipos que mejor patentizan la decadencia de la raza española. ¡Qué provincias las del Mediodía, señor Dios de los ejércitos! ¡Qué hombre el tal Pachequito! Perezoso, ignorante, sensual, sin energía ni vigor, juguete de las pasiones, incapaz de trabajar y de servir a su patria, mujeriego, pendenciero, escéptico a fuerza de indolencia y egoísmo, inútil para fundar una familia, célula ociosa en el organismo social... ¡Hay tantos así! (156)

Thus, Pacheco, as "the object of [Asís's] desire is a hybrid of opposing tendencies that dismantle the north/south, civilization/barbarism binary" (Tsuchiya 152). Racial divisions are blurred in the figure of Pacheco, making him acceptable as a lover, and even possibly as a husband. In this way the novel partially collapses racial divisions in the figure of Pacheco as a representation of a healthy racial hybrid, yet the gitana, who is marginalized by race, gender, and class, still represents a threatening racial Other contained through the reenactment of the racial stereotype that fixes her identity in a few undesirable and dehumanizing traits.

While the narrator/protagonist and implied author are complicit in the stereotyping and marginalization of the gitana in Insolación, the various levels of narration in "Maldición gitana" and the distance between 
narrator and implied author bring the racism implicit in this process to the fore. Here, the stereotyped gypsy serves as a scapegoat and catalyst for hostilities between two brothers. Moreover, in this tale racial hybridity is a negative attribute that creates the conflict that leads to fratricide. The story begins with the intra- and homodiegetic narrator, Gustavo Lizana, telling the intra- and heterodiegetic narrator how on January $\mathrm{I}^{\text {th }}$, the day after a dinner party with only 13 guests, one of the Mayoral brothers accidently shot the other because, supposedly, of a gypsy's curse and the number $13 .{ }^{7}$ What Gustavo inadvertently reveals, however, is a subtext of racial tension within the family, and consequently, within Spanish society as a whole, that is brought to the fore by this incident.

Gustavo recounts that while out hunting with the Mayoral brothers, Leoncio and Santiago, the three of them came across a gitanilla. Admiring the blonde and fair-skinned Santiago's good looks, the young gypsy woman proceeded to address him with a piropo and to offer to tell his fortune. Santiago responded by insulting her looks in racial terms: "- $i$ Qué buenaventura vas a darme tú? - exclamó Santiago -. ¡Para ti la quisieras! ¡Si tuvieses ventura, no serías tan fea y tan negra, chiquilla!" (320). The gitanilla immediately exchanges her offer for a curse: "-ino quieres buenaventuras, jermoso? Pues toma mardisiones ... Premita Dios..., premita Dios..., ique vayas montao y vuelvas tendío!” (320). The hunters' dogs thereupon attack the gypsy. But, as soon as one manages to bite her leg, they are called to heel, and the gypsy gets away. At this point in the tale, the anonymous, intra- and heterodiegetic narrator intervenes and the two narrators complete the story together: "Leoncio, vivo, moreno, delgado; Santiago, rubio y algo más grueso... ¿ ¿Fue en esa cacería donde...? Donde Leoncio, creyendo disparar a un corzo, mató a Santiago de un balazo en la cabeza -respondió lentamente Gustavo" (32I).

While Gustavo emphasizes the connection between Santiago's death, the number I3, and the gypsy's curse, there are other clues in the story to suggest that Gustavo is an unreliable narrator, and that Santiago's death was motivated by envy regarding the different racial features of the two brothers.

From the beginning, Leoncio and Santiago are presented as opposites, which immediately connects their story to that of Cain and Abel and the tradition of using brothers to represent antithetical, yet complementary, characteristics, a connection that I explore in more detail below. ${ }^{8}$ We are told that Leoncio is high-strung and extremely hot tempered ("nervioso y vehemente hasta lo sumo"), whereas Santiago is of an equanimous and peaceful temperament ("de un genio igual y pacífico"). And towards the end of the story the intra- and heterodiegetic narrator reminds us of their 
physical differences: Leoncio is dark, and thin ("moreno, delgado"), whereas Santiago is blonde and somewhat more robust ("rubio y algo más grueso") (32I). These contrapositions tie temperament to race, the darker brother is impulsive and irascible while the fairer brother is calm and levelheaded (the story, however, will lead us to question this assessment, as we shall see). It is also an example of fixity (where a few characteristics metonymically stand in for the whole person), of skin color as the primary marker of race, and of the recurring binary division between the good fairskinned person and the bad dark-skinned person.

While Gustavo insists that few brothers could ever be as close, love each other as much, or live in such perfect harmony, there is a suggestion that the difference in their physical traits and attractiveness is a source of tension. First, the day before Santiago's "accidental" murder, there is a gathering organized by the mother of a young woman to whom Santiago is attracted. Gustavo disorients the reader by saying: "Sutilizando mucho, creo que esta pasión de Santiago tuvo su parte de culpa en la desgracia que sucedió. Ya diré porque" (319). This implies that this woman might have been a source of conflict between the brothers. While Gustavo takes the story in a completely different direction - claiming that Santiago's love interest is what made Santiago both insult the gypsy and attend a dinner with only iz guests, and consequently cause his own murder - the reader is left wondering if Leoncio was jealous that his brother was the object of this woman's affections.

The resemblance in Leoncio and Santiago's story to that of Cain and Abel reinforces this reading because of the theme of envy and the different racial characteristics ascribed to the two brothers. First, there is no clear motive for the murder in either story, although "envy" can be assumed to be the cause in both cases. ${ }^{9}$ And just as later Jewish interpreters and scribes maintained that Cain's envy involved his desire for the most beautiful woman (Kim 8I-83), there is the suggestion that Leoncio is envious of his brother's love interest. While we cannot be sure if Santiago's love interest does indeed prefer Santiago over Leoncio, the gypsy's own fixation on Santiago's European beauty, as well as Gustavo's emphasis on Santiago's fairness and good looks in this same scene, indicates that he is considered more attractive, even by dark women such as gypsies. ${ }^{\mathrm{IO}}$ Thus, Leoncio, like Cain, is the older brother whose "gifts" are rejected. Also, in medieval and subsequent depictions of Cain, racial difference is underscored as he is frequently depicted as a Jew, and as a redheaded Judas, whereas Abel became a symbol of Christ and European gentiles (De Vries, "Cain;" "Abel"). The connection between Leoncio, Cain, and Judas is further reinforced by the number 13. Leoncio, Santiago, and Gustavo go 
hunting on "cierto día de San Leoncio," which falls on January $13^{\text {th }}$, a connection the reader is encouraged to make by Gustavo's remark that: "No cabe olvidar la fecha" (319). Thus, Leoncio, like Judas, the infamous thirteenth dinner guest at the last supper, has a clear association with the number I3. Moreover, Judas, like Leoncio, is the guest at a dinner gathering where he (Leoncio/Judas) will be responsible for the death of another guest (Santiago/Jesus). Finally, Cain is also associated with the number 13 though his connection to Judas and for supposedly having killed his brother on Friday the $3^{\text {th }}$ (Broach), just as Leoncio will kill his brother on the January $13^{\text {th }}$.

While Leoncio is neither Jewish nor redheaded, his dark complexion and hot-temper associate him with the Oriental element of Spanish culture that included those with Arabic, Jewish, and gypsy blood. ${ }^{\text {II }}$ Furthermore, both the gypsies and the Jews were social outcasts who, like Cain, according to legend, were forced to flee Egypt, and were marked by the curse of God. Sebastián Herrero, in his sketch of the gitana, explicitly links the Jews and the gypsies in their status as pariahs when he says that the gypsy woman is "condenada como los judíos á una proscripción eterna" (292). And in her costumbrista sketch Blanca de los Ríos's asserts that the gypsies are a race cursed by God, which can be linked to the idea of the mark of Cain (597), and to Cain's and the gypsies' frequent association with the devil. Charnon-Deutsch's dedication of her book The Spanish Gypsy to Roma Holocaust victims is just another reminder about how Jew and gypsy were linked together as the bad and threatening racial Other that needed to be distanced from the rest of society. All this suggests different interpretations of the title of the story itself: the "maldición" might refer to the curse the gypsy placed on Santiago, or it might refer to the curse of the gypsies as a race, a racial curse that is actually shared by the Mayoral brothers, and perhaps even by Gustavo.

Thus, Leoncio is associated with Cain - and by extension Judas - and the gypsy as a racial/Oriental Other, a contaminated element of Spanish society, and as a pariah cursed by God. This makes Santiago's racial insult of the gypsy an oblique insult of his brother and a possible motive for murder. In contrast to Leoncio, Santiago not only embodies the characteristics of the cristiano viejo, but his very name, Santiago, alludes to Santiago Matamoros, the Spanish patron saint who, according to legend, helped the Spaniards expel the Moors from the Iberian Peninsula. This implies Santiago's racial superiority over his brother as well as Leoncio's connection to the Moors. The gypsies' own connection to the Moors is underscored both by their classification as Oriental, their association with 
Andalusia, and by the gypsies' supposed Egyptian/Arabic origins, an association that is explicitly made in the story (320).

The issue of race is also explored on the level of narrative itself through the unreliable intra- and homodiegetic narrator Gustavo Lizana. Gustavo's description of the young gypsy woman is nothing but a reenactment of the stereotype seen above. She elicits an ambiguous reaction from the narrator who admires the "salvaje atractivo" found in her dark skin, slanted eyes that shine like two black diamonds, rags, and filth (320). While he finds her attractive - a comment that contrasts markedly with Santiago's description of her as ugly - he also fears her and pegs her as a witch and a bird of ill omen (32I). As a woman and a social outcast, the gitanilla is easier to blame for Santiago's murder than Leoncio, a member of the same social class and sex. Gustavo denies Leoncio's racial Otherness in order to maintain the concept of racial hierarchy that depends on the belief in the pure blood of the "antigua y pudiente" Mayoral family, to which Leoncio and Santiago belong, and the binaries of Western/Oriental and Non-semitic/Semitic. What this ignores, however, is the fact the Leoncio and Santiago are brothers, and consequently share the same racial heritage. In other words, they all share, to some extent, that gypsy's racial "curse," the curse of Semitic/Oriental blood explored above. Moreover, the Mayoral family's origins in Extremadura, which was part of the Umayyad Caliphate of Córdoba and the Taifa of Badajoz, clearly ties both brothers to the Moors.

The story ultimately takes an ambiguous position on the question of racial determinism, as it seems that we are either to believe that the gypsy truly is a witch capable of casting curses that come true, or that Leoncio's racially-determined hot temper and impulsiveness lead him to brutally murder his own brother. Yet, the racist attitudes of Santiago are equally cruel (Gustavo refers to his racial slur as "una frase dura y hasta cruel, una frase fatal" [320]). Not only does he insult the gypsy woman for no reason, but he also appears to have been the most reluctant to call back the dogs when they attack her. ${ }^{\mathrm{I}}$ The brutality of Santiago's racism is also underscored by the oblique reference to the discrimination against those with Moorish blood (Santiago's name as a reference to Santiago Matamoros). Santiago's behavior actually reveals that he is as impulsive and hot-tempered as Leoncio, which, if we were to subscribe to racial theories on temperament, is not surprising since they are brothers and share the same "blood." This points to skin (dark vs. fair) as an unreliable sign of race that does not coincide with character. Furthermore, the conflation of gypsy, Moor, and Jew, as representations of the Oriental Other 
tie all three characters' heredity together and to that of the gypsy, despite Gustavo's desire to maintain clear racial divisions.

Interestingly, Gustavo's recourse to superstition parallels his use of the racial stereotype and underscores his own uncivilized predisposition (he is superstitious). ${ }^{13}$ Superstitions seek precisely to create a cause-andeffect relationship where there is none in order to give the believer a sense of control over situations over which s/he has none (Foster and Kokko 3I). Just as Gustavo associates the tragic events with the presence of only thirteen guests and a gypsy's curse, he holds onto the racial stereotype of the gitana because it allays his own fears that the Oriental, Semitic, and supposedly diabolical attributes that he projects onto the gypsy may actually exist in Leoncio, Santiago, and even in himself. Thus, while Carmen Parrilla argues that Gustavo persuades the intra- and heterodiegetic narrator that superstition and curses do indeed have some basis in reality (366), it is my contention that the implied author wants us to reject Gustavo's account as unreliable (based on superstition), and show how his own anxieties about racial purity are managed through his recourse to the racial stereotype that holds in place a Manichean world of bad, dark, female Other and good, fair, male self. In other words, Gustavo seems only able to understand Santiago's murder in terms of his racial and gender prejudices about the diabolical powers of gypsy women, and his superstitious beliefs about the number $\mathrm{I} 3$, yet is unable to see how Santiago's insult of the gypsy's "ugly blackness" could have been interpreted as an oblique insult by Leoncio, who is metonymically signaled in the text precisely by his dark complexion. While we see a similar process in Insolación, the distance between the implied author and the narrator is greater in this story because the narrator is male and superstitious, whereas Asís, the narrator of chapters five and six of Insolación, is female, and not particularly superstitious (she views the gypsy's fortune-telling as an amusing diversion, but does not take it seriously). This distance seems to allow for sharper critique of the psychological dynamics of the stereotyping process with which the implied author was more complicit in her novel.

"La novela de Raimundo" brings the issue of gender more notably into the discussion of race. The story opens with the extra- and heterodiegetic narrator presenting Raimundo, the protagonist and intra- and homodiegetic narrator, as a representation of Spanish "whiteness" or "Europeanness": he has a proportionate build, correct features, blues eyes, a pleasant smile and white skin. Although these physical features are markers of racial superiority, they also convey a bourgeois normalcy or "sosería" that suggest that he was "formado por la Naturaleza para ser a 
los cuarenta buen padre de familia y alcalde de su pueblo" (328). It is for this reason that his interlocutors at the spa, a space clearly restricted to privileged races and classes, find it hard to believe that such a man could possibly have a "novela" to share. Raimundo quickly explains that when a group of gypsies came to town, it broke the monotony of that town's dull existence and provided him the material for his "novela romántica" (32829).

From the moment they arrive in town, the gypsies elicit an ambivalent reaction from Raimundo who externally sees "miserias, andrajos y densa capa de mugre" but is also drawn to what he refers to as their "noble hermosura y pintoresca originalidad" (329). This contrast replicates the idea promoted by nineteenth-century French travellers to Spain that the gypsies' "outer 'dirt' shielded [an] inner 'purity"' (Charnon-Deutsch 70). Raimundo is particularly drawn to the beauty of a sixteen-year-old gitanilla. The woman has a young child and also happens to be the wife of the leader of the clan, a fact that the narrator claims not to have known at the time. First we are given a hackneyed description of the gypsies who live a filthy, vagabond existence that is sustained by theft -despite the gypsies' ragged appearance, they have deposited "miles de duros en ricas onzas españolas" in a local bank, money that could not have been earned by their work as blacksmiths (329). The gitanilla herself is nothing but a reenactment of the young, pretty, ragamuffin stereotype seen, for example, in costumbrista depictions of the time: she has greenish-tinged skin, vibrant, almond-shaped eyes, and hair that is so black that it is almost blue; she wears an old torn dress and false corals. This cliché is then immediately juxtaposed to that of the old, ugly gypsy woman/witch who happens to be stirring the contents of a caldron inside the tent. The fusion of these two images is a technique that serves as a reminder of the deception concealed by the beauty of the young gypsy woman, who was said to age rapidly (Charnon-Deutsch 62; 187). Moreover, the two images are converted into a single racial stereotype by a reference to the whole scene as one of Goya's caprichos (329), and Raimundo says this shortly after insisting that the gitanilla alone "estaba reclamando un pintor que se inspirase en su figura" (329). In other words, there is a desire to gain control over the racial Other both by objectifying the gypsy woman in both narrative and pictorial imagery.

One day Raimundo takes it upon himself to enter the tent of the young gypsy woman who immediately offers to tell him his fortune. Afterwards, the gitanilla picks up her crying child and places it on her breast. When the child bites her "cruelmente," the gypsy girl lets out a cry and "lightly" hits the child, who breaks out into a "llanto desconsolador" (329). The child's 
shrill screams in reaction to the gitanilla's "dos azotes ligeros," not only lead the reader to question Raimundo's portrayal of her treatment of the child, but also bring the father running into the tent. ${ }^{\mathrm{I}}$ The gitano comes into the tent cursing loudly and brutally kicks his wife, knocking her to the floor. His anger appears to have been aroused both by his wife's unsatisfactory care of their child and by the discovery of another man, a payo at that, in his wife's company. After helping the gitanilla off the floor, Raimundo reprimands the woman's husband and threatens to alert the authorities. Clearly intimidated, the gypsy man assumes a submissive role vis-à-vis Raimundo, and desperately tries to calm him down. While the gypsy man's violence is inexcusable, and while Raimundo portrays himself as the gitanilla's savior, it is clear to the reader that the scene is partially an assertion of Raimundo's power and dominance over a man of another race, and not just any man, but a man who also happens to be the leader of the gypsy clan (329-30). According to Michael S. Kimmel, hegemonic models of masculinity require constant demonstrations of manhood enacted by social or physical dominance over other men, thereby creating a hierarchy in which certain males necessarily dominate others (Kimmel 272-75). Raimundo's invasion of the living space of another man's wife in order to observe her "exotic otherness," and his subsequent assertion of his authority over the gypsy as a white man with access to institutionalized justice humiliates and "feminizes" the gypsy and threatens his sense of manliness within a macho gypsy culture. Moreover, despite Raimundo's proclaimed intentions, his behavior does not protect the woman in question, but actually leads to her murder, or, in Parrilla's words, "metafóricamente puede decirse que Raimundo ha cavado la tumba de la gitana" (370).

After this scene, Raimundo departs on what seems to be good terms. Yet, despite the gitano's displeasure with his presence, Raimundo returns to the gitanilla's tent the next day, and every day afterwards. Lest his interlocutors at the spa suspect that he was actually in love with the gypsy woman, he takes it upon himself to explain that he felt nothing more towards the gitanilla than a curiosity about her exotic nature:

¡No arméis alboroto ni me deis broma! Yo no sentía nada parecido a lo que suele llamarse no ya amor, sino solo interés o capricho por una mujer. Quizá por obra de la suciedad salvaje en que la gitana vivía envuelta, o por el carácter exótico de su hermosura de dieciséis abriles, lo que inspiraba una especie de lástima cariñosa unida a un desvío raro; yo no concebía, con tal mujer, sino la contemplación desinteresada y remota que despierta un cuadro o un cachivache de museo. A veces me creía inferior a ella, que procedía de raza más pura y noble, de aquél Oriente en 
el que la Humanidad tuvo su cuna; otras, por el contario, se me figuraba un animal bravío, un ser de instinto y de pasión, a quien yo dominaba por la inteligencia. (330)

This passage serves as a clear example of Homi Bhabha's theory of the racial fetish. First the gypsy women evokes ambivalence, or contradictory feelings of scorn and attraction: the narrator feels both affectionate pity and a morbid fascination towards this woman, and he claims that she is both a member of the most pure and noble race, and an untamed animal whom he surpasses in intellect. The anxiety this woman arouses as the unknowable Other is partly appeased by the narrator's recourse to the racial stereotypes that he must reenact to fix an identity that ultimately cannot be known. Her identity is not only recreated and controlled through language, but also through references here and earlier to her objectification in painting ("cuadro") and as an objet d'art ("cachivache[s]").

Yet, by expanding on Bhabha's theories with Peter Brook's connection between narrative and epistemophilic desire, or the desire to know, we may also better understand Raimundo's role in the woman's murder. According to Brooks, modern narrative is often set into motion by the desire for a female body that "appears to hold within itself ... the key to satisfaction, power, and meaning" (8). This urge to simultaneously satiate sexual and intellectual appetites drives the narrative. The contradictory nature of desire, which is energy that seeks relief through the destruction of itself, as well as the parallels between scopophilia and epistemophilia, lead to the desire to unveil, consume, and even destroy the body that excites the eye, the mind, and the flesh. Thus, not surprisingly, in this story, the gypsy woman's body is not only a vehicle for asserting Raimundo's superiority over a gypsy man - his insistence on visiting another man's wife despite this man's objections, is a form domination of the man himself- but also an object to be simultaneously understood and destroyed in order to satiate the contradictory desires and anxieties it evokes. These desires can explain why Raimundo continues to visit the gypsy woman daily despite the gitano's displeasure with his visits and the clear danger Raimundo's presence poses to the gypsy woman.

According to Lou Charnon-Deutsch, the most common gypsy narrative was the "heterosexual love story" between a gypsy woman and a white man: "In the vast majority of stories the mismatched union consists of a man, superior in many ways but often repressed, who is attracted to a woman whose carefreeness and sensual faculties are magnified by comparison" (240). The gitana's Otherness is overdetermined in that she is differentiated from the male protagonist in terms of race, gender, and 
class. The man's initial fascination with this femme fatale not only threatens the bourgeois institutions of family and nation, but also traditional gender hierarchies since "the man who falls prey to her seductions is often portrayed as a castrated, feminized figure no longer in control of his actions" (240). Thus, returning to Brook's concept of epistemophilia, the gypsy woman and her body are not only the object of the protagonist's sexual desires, but also of his yearning to transcend his own repressed, bourgeois existence through knowledge, in the literal and Biblical sense of the word, of the exoticized Other. This woman seems to hold the key to what is missing in the protagonist's own mundane existence. This is not entirely different from the dynamic we explored in Insolación except for the fact that a desiring female subject seems to account for the absence of the link between sexual desire, violence, and domination, at least in this instance. The temporary inversion of traditional hierarchies caused by the protagonist's enchantment with this woman, must be overturned, and his desire squelched, which is achieved through death, in the literal and in the figurative sense, that is, through the death of sexual desire and through an inscription of meaning onto the female body, or stated otherwise, by substituting the real woman with a racial fetish that can be more easily fixed and known.

This is precisely the scenario that plays out in Prosper Mérimée's Carmen, clearly an intertext for Pardo Bazán's story. Mérimée’s novella begins with an anonymous French scholar/narrator who comes across the infamous bandit don José during his travels in Spain. Don José introduces the narrator to Carmen, and later, while imprisoned and waiting to be garroted, tells the narrator his story of how Carmen seduced him and led him to a life of crime. When Carmen refused to be faithful and told don José that she didn't love him as much as she did before, he murdered her in a fit of jealousy and surrenders himself to the authorities. José Colmeiro's assertion that the "close connection between desire for the other and its eradication is encapsulated in the novel's misogynist Greek epigraph," which equates "orgasm and the moment of death," further highlights the dynamic studied by Brooks in which sexual desire and intellectual curiosity merge in narrative, particularly in narratives driven by the desire for a female body (Colmeiro I40). The link between intellectual and sexual desire is strengthened by the presence of a French narrator, an archeology scholar, who has come to Spain in search of cultural knowledge (134). Although seemingly partaking in the emotions José feels towards the gypsy woman, he is able to "safely project his desires and anxieties on to the figure of don José without the fear and danger of personal involvement with the other," a dynamic similar to that which we find in "La novela de 
Raimundo" where Raimundo disowns his involvement in the gitana's murder by portraying himself as merely an impartial observer of a murder for which he actually served as a catalyst (Colmeiro ${ }^{2} 36$ ). Not only do the references to Raimundo's story as a novela allude to Mérimée's nouvelle, but also Raimundo, like the narrator in Carmen, proceeds to retell his story for the delectation of other "civilized" white, male, listeners/readers. Thus, in both tales, "the fundamental ambiguity of the love/hate, attraction/repulsion toward the other ultimately reveals the barbaric and primitive side hidden side behind the cultured and civilized mask" (Colmeiro I40).

Returning specifically to Pardo Bazán's story, one day, after Raimundo's visits had already started to become less frequent, the whole gypsy tribe gets up and leaves the town. A month later, stray dogs dig up a woman's body in the surrounding mountains. The authorities are unable to find out anything about the circumstance of the gitanilla's murder because the gypsy clan unanimously asserts that she had separated from the rest of them, and that they, in any case, had never come near the Sierra de los Castros, the place where the body had been buried. While the authorities come up with nothing, Raimundo speculates on the cause of the murder by quoting Cervantes's novela "La gitanilla" about how easily men will kill their wives and daughters out of jealousy and a desire to protect their honor. In this way, and by insisting from the very beginning that his involvement in the "novela" was completely "involuntario," Raimundo attempts to exonerate himself from any blame. Yet, despite his intentions, the intertextual reference and his closing words do precisely the opposite, implicating not only him, but also the rest of Spanish society, in the woman's murder. First, the words of Cervantes's narrator echo Pardo Bazán's own comments about gender violence during her time in which she argued that the role of passion and honor in wife murder was a romantic invention that allowed men to avenge their wounded egos, reassert their dominance, and get off scot-free (Smith 697). Moreover, just as in this story, society consistently turned a blind eye towards such events, thereby essentially condoning them, as the gypsy clan and the authorities in this story do (Smith 70I; Versteeg 137). Thus, a parallel is drawn between the machismo of the gypsies and that of contemporary Spanish men, a connection that is reinforced in "La mujer española" by Pardo Bazán's Orientalization of Spanish men: "Y el punto en que la tradición se impone con mayor fuerza al español, porque late, digámoslo así, en el fondo de su sangre semítica, es el de las cuestiones relativas a la mujer" (88; emphasis mine). Thus, Pardo Bazán erases the racial difference between gypsies and payos in the story by revealing the violence of the 
patriarchal customs of both, and in her essay by referencing their Moorish/Jewish/Oriental lineage as a source of Spanish men's sexism and violence against women. Also, Raimundo's recognition that jealousy was the gitano's motive for killing his wife, is in fact, a recognition of the role he himself played: the husband's jealousy was directed at Raimundo, who defied his desires, and continued to spend time with his wife.

While Susan McKenna has read the literary allusion to Cervantes's tale as an opening up of Pardo Bazán's narrative that allows for the suggestion of an alternative ending of female emancipation, the ambiguity of Cervantes's own gypsy "novela" problematizes such a reading. Not only does his protagonist, Preciosa, deviate little from other portrayals of female virtue of the time, this favorable portrayal can be read precisely as proof of her racial superiority since it is revealed that she is not "really" a gypsy after all. Thus, the intertextual reference, merely reproduces the ambivalence towards the racial Other that we find in Pardo Bazán's tale. While "La novela de Raimundo" clearly indicts patriarchy for its violence against women, it takes an ambiguous position on race. It reenacts the stereotype as a way of fixing and controlling the identity of the racial Other while at the same time underscoring the connections between racism and sexism, making it impossible to critique one and not implicitly the other. Specifically in the case of Raimundo's novela we are asked to scrutinize his "involuntary" racism and misogyny, and the role they play in the gitanilla's murder. We also are forced to look at the importance of being marked by both race and sex since, while the gitano suffers from being publicly "feminized" by a white man, the woman is the true victim of the story, punished for both her race and her sex in order for men of both races to preserve their dominance and sense of self as superior, a maneuver that is also sanctioned by society as a whole.

Thus, the three works studied here provide a variety of insights regarding questions of race in late nineteenth century Spain. The costumbrista sketch of the gitana in Insolación participates in the process of racial stereotyping that both takes delight in the exotic otherness of the gypsy at the same time that it subordinates and erases the real people with a stereotype that claims to represent them. Although the sketch was written by a woman with progressive attitudes about women, it conflates racial and sexual difference - as all three gypsy characters are women - and subjects the gitana to a double determinism that racializes women and feminizes the racial other. This dynamic corresponds to Pardo Bazán's own assertion in "La mujer española" that "los tipos étnicos más puros, así en lo físico como en lo moral, en el pueblo se conservan, $\mathrm{y}$, sobre todo, en la mujer del pueblo" (IO8). At the same time it makes this very racial 
difference palatable in the figure of an upper-class, Andalusian man who embodies a celebrated Spanish racial hybridity. Pardo Bazán's later "Maldición gitana," however, further blurs the division between the dominant subject and the racial Other by showing the "impurity of blood," to use Joshua Goode's term, that all Spaniards share, and by presenting this hybridity as a negative trait. It also underscores the violent and arbitrary nature of racism. The last story, with its obvious critique of the narrator's unacknowledged misogyny, is strongest in its implied indictment of racism against the gypsies. Here, in contrast to Insolación, the conflation of race and gender in the figure of the young gypsy woman make it impossible to critique misogyny and not racism. If we return to our comparison with Mérimée's Carmen, one of the principal differences between the two works is that while the implied author positions the reader to sympathize with don José because of his mistreatment by Carmen, here the text seems to condemn Raimundo, and society, for their role in the gypsy woman's murder, a murder that goes unpunished (unlike in the case of Carmen's). In this way Pardo Bazán adds her own feminist twist to the Carmen myth, and in so doing, simultaneously writes a work that strongly condemns Spanish society's racism against the Roma as well.

Southern Illinois University (Carbondale)

NOTES

I Since the term fixity is used by Homi Bhabhi to describe a specific dynamic in the process of racial stereotyping, I italicize it here and elsewhere in the essay.

2 For example, in Blanca de los Ríos's sketch of the gitana in Las mujeres españolas, americanas y lusitanas pintadas por sí mismas (188I), the gypsy exhibits dark, coppery skin, wild, black hair, and bright eyes with a fiercely penetrating gaze (590-92; 596). Moreover, they exhibit a "satánica astucia" and "infernal maquiavelismo" (595).

3 Akiko Tsuchiya was the first to study the Orientalization of the character of Diego Pacheco.

4 Despite the overwhelming linguistic evidence by the I87os of the Indian origins of the gypsies, many Spaniards continued to adhere to a belief in the gypsies' supposed Egyptian origins because it tied them even more closely to the Islamic influence in Andalusian culture (Charnon-Deutsch 7-9).

5 In both Insolación and "Maldición gitana" the gypsies are referred to as "egipcias" (Insolación 60; "Maldición gitana” 320). 
6 In “La mujer española,” Pardo Bazán writes: “El grupo andaluz y madrileño revela afinidades estrechísimas: si me propusiese buscar en un pasado prehistórico la filiación de su carácter, diría que descubre la preponderancia del elemento semítico y africano" (II5). In contrast, she writes that Galicians and Asturians belong to "el territorio propiamente céltico" (II5).

7 They go hunting on "cierto día de San Leoncio," which falls on January $13^{\text {th }}$ (319).

8 According to Ad de Vries, brothers, as is the case with Cain and Abel, and Leonio and Santiago, tend "to represent two opposites, which, in the end, have a synthesizing complementary function, e.g. life/death, sunrise/sunset, bad/good, hunter/shepherd, vertical mountain/horizontal valley, etc." ("Twins").

9 Angela Y. Kim has studied the lack of motive in Cain's murder of Abel and argued that subsequent interpretations emphasized the motive of envy in order to "deflect attention away from God who chooses, in a capricious way, one sacrifice over another" (65). Kim's emphasis on the lack of clear motive for the murder in the Biblical story suggests yet another similarity between the Old Testament account of Cain and Abel and Pardo Bazán's tale. In other words, if the readers rejects mere accident or supernatural explanations, there is no clear motive for Leoncio's murder of his brother either, only the suggestion of envy.

Io According to Gustavo, Santiago "era un muchacho arrogante, rubio y blanco, y en aquel instante, subido al poyo de montar y con un pie en el estribo, con su sombrero de alas anchas, su bizarro capote hecho de una manta zamorana, de vuelto cuello de terciopelo verde, y sus altos zahones de caza, que marcaban la derechura de la pierna aún parecía más apuesto y gallardo" (320).

II José Colmeiro notes that in Prosper Mérimée's Carmen, don José initially is not sure if Carmen is Andalusian, Jewish, Moorish, or Gypsy, which leads him to assert that they become essentially "interchangeable versions of the 'Oriental"' (135).

I2 "Uno de ellos hincó los dientes en la pierna desnuda de la mujer, que dio un chillido. Esto bastó para que Leoncio y yo, y todos, incluso Santiago, nos distrajésemos de la maldición y pensásemos únicamente en salvar a la bruja moza, en riesgo inminente de ser destrozada por la jauría" (32; emphasis mine).

I3 While Gustavo tries to rationalize his superstitious thinking by telling a story about "coincidences" involving the number I3, his involuntary negative reaction upon hearing that there are thirteen dinner guests - as well as his instinctual relief upon hearing that a fourteenth guest has arrived - undermine his efforts. Furthermore, in the opening paragraph to the story, the hetero- and extradiegetic narrator makes a point of stressing how despite the fact that 
educated people always claim to be free of superstitious thinking, within ten minutes of the topic coming up, "cada cual sabe alguna historia rara, algún sucedido inexplicable, una 'coincidencia"' (318). This is the context and background for introducing the character of Gustavo Lizana who, despite his education and social class, is incapable of seeing any other explanation for Leoncio's murder other than a gypsy's curse and the recurrence of the number I3.

I4 There seems to have been little consensus as to whether gypsy women were good mothers. While Sebastián Herrero lauds gypsy women for possessing a maternal instinct that surpasses that of European women, De los Ríos claims that gitana's savage nature prevents her from giving her children the love and affection they need, and the waitress in Insolación tells Asís that gypsy women rent out their children to other gypsy women who go want to go begging and who most likely mistreat the children (Herrero 297; De los Ríos 594; Pardo Bazán, Insolación 63).

\section{WORKS CITED}

в навна, ном г. "The Other Question: Stereotype, Discrimination, and the Discourse of Colonialism." The Location of Culture. London: Routledge, 1994.

B R о о KS, P E T E R. Body Work: Objects of Desire in Modern Narrative. Cambridge: Harvard UP, I993.

CANT OS CASENAVE, MARIETA “'Gitanofilia': de algunos rasgos costumbristas del 'género andaluz."'Romanticismo 6: Actas del VI Congreso: El costumbrismo romántico, marzo 27-30, de 1996. Roma: Bulzoni, 1996. 65-70.

C ERVAntes, mi gu E De. "La gitanilla." La gitanilla; Las dos doncellas. Ed. Rosa Navarro Durán. Madrid: Alianza, 2005. 29-ı19.

C HAR N O N-DE U T S CH, L O U. The Spanish Gypsy: History of a European Obsession. University Park: Pennsylvania State UP, 2004.

colmeiro, josé F. "Exorcising Exoticism: Carmen and the Construction of Oriental Spain." Comparative Literature 54.2 (2002): 127-44.

DE LOS Ríos, B LANCA. "La gitana." Las mujeres españolas, americanas y lusitanas pintadas por sí mismas. (188I). Vol. I. Barcelona: Establecimiento TipográficoEditorial de Juan Pons, 260-75. Biblioteca Virtual: Miguel de Cervantes. Web. 26 Jul. 2012.

D E VRIES, AD. "Abel." Elsevier's Dictionary of Symbols and Imagery. 2004.

-. "Cain." Elsevier's Dictionary of Symbols and Imagery. 2004.

—. "Twins." Elsevier's Dictionary of Symbols and Imagery. 2004.

D O RCA, T ONI. "La recreación de la España pintoresca en la novela moderna: El caso de Insolación." Tribuna: Cadernos de Estudios da Casa Museo Emilia Pardo Bazán 4 (2006): II3-3I. 
FERnÁNDEZ CifUEnTES, Luis. "Southern Exposure: Early Tourism and Spanish

National Identity." Journal of Iberian and Latin American Studies 13.2-3 (2007): I33-48.

FOSTER, KEVIN R. AND HANNA KOKKO. "The Evolution of Superstitious and Superstition-like Behaviour." Proceedings of the Royal Society B 276.1654 (2009): 3I-37. Royal Society Publishing. Web. I6 Jun. 2014.

GILMAN, SAN DE R. Difference and Pathology: Stereotypes of Sexuality, Race, and Madness. Ithaca: Cornell UP, I990.

G O ODE, Jo S H A. Impurity of Blood: Defining Race in Spain, 1870-1930. Baton Rouge: Louisiana State UP, 2009.

HERRER 0, SEBAST IÁN. "La gitana." Los españoles pintados por sí mismos. Madrid: I. Boix, I843. Internet Archive. Web. I8 May 20I4.

но ок, D Е в к. "The Racial Stereotype, Colonial Discourse, Fetishism, and Racism." Psychoanalytic Review 93.5 (2005): 701-34.

KI M, ANGELA Y. "Cain and Abel in the Light of Envy: A Study in the History of the Interpretation of Envy in Genesis 4.I-I6." Journal for the Study of the Pseudepigrapha I2.I (200I): 65-84.

KIM MEL, M ICHAEL S. "Masculinity as Homophobia: Fear, Shame, and Silence in the Construction of Gender Identity." The Masculinities Reader. Eds. Stephen M. Whitehead and Frank J. Barrett. Cambridge: Polity, 200I. 266-87.

MC KE N NA, s US AN. Crafting the Female Subject: Narrative Innovation in the Short Fiction of Emilia Pardo Bazán. Catholic U of America P, 2009.

mart In - MÁrqueZ, susan. Disorientations: Spanish Colonialism in Africa and the Performance of National Identity. New Haven: Yale UP, 2008.

MÉ Ri mé E, P R OS PE R. “Carmen." Carmen and Other Stories. Trans., intro., and ed. Nicholas Jotcham. Oxford: Oxford UP, 1998. I53.

PARRILla, CARMEN. "La mujer gitana en la literatura decimonónica finisecular española: Procedimientos constructivos en la obra de Emilia Pardo Bazán.” Tribuna: Cadernos de Estudios da Casa Museo Emilia Pardo Bazán 6 (2008): 35972.

PARDo BAZÁn, E Milia. Insolación. Ed. and intro. Jennifer Smith. Newark: European Masterpieces / Cervantes \& Co., 2OII.

—. "Maldición gitana." Cuentos completos. Vol. I. Ed. Juan Paredes Núñez. La Coruña: Fundación "Pedro Barrié de la Maza conde de Fenosa", I990. 3I8-2I.

—. "La mujer española." "La mujer española” y otros escritos. Ed. Guadalupe GómezFerrer. Madrid: Cátedra, I999. 83-ıI6.

—. "La novela de Raimundo." Cuentos completos. Vol. I. Ed. Juan Paredes Núñez. La Coruña: Fundación "Pedro Barrié de la Maza conde de Fenosa”, 1990. 328-3I. Pe Re i Ra - m u Ro, ca R m e N. Género, nación y literatura: Emilia Pardo Bazán en la literatura gallega y española. West Lafayette: Purdue UP, 2013. 
ROACH, J OHN. "Friday the I3th: Why We Fear It; Why It Can't Strike Again in 2or2." National Geographic: News. I3 July 2012.

SAID, EDWARD. Orientalism. New York: Vintage, I994.

Smith, JEnn ife R. "La violencia de género en dos cuentos de Emilia Pardo Bazán." La literatura de Emilia Pardo Bazán. Eds. José Manuel González Herrán et al. A Coruña: Real Academia Galega, Casa-Museo Emilia Pardo Bazán, Fundación Caixa Galicia, 2009. 697-705.

TO RRECILLA, JES Ú S. La España exótica. La formación de la imagen española moderna. Boulder: Society of Spanish and Spanish American Studies, 2004. TS U н ну А, Акіко. "Gender, Orientalism, and the Performance of National Identity in Pardo Bazán’s Insolación." Marginal Subjects: Gender and Deviance in Fin-deSiècle Spain. Toronto: U of Toronto P, 20II. I36-6r.

VALIS, N OËL. “Confesión y cuerpo en Insolación, de Emilia Pardo Bazán.” Estudios sobre Emilia Pardo Bazán: In Memoriam Maurice Hemingway. Ed. José Manuel González Herrán. U de Santiago P, 1997. 321-5I.

versteeg, margot. "Gender-Based Violence in the Short Fiction of Emilia Pardo Bazán.” Au Naturel: (Re)Reading Hispanic Naturalism. Ed. J. P. Spicer-Escalante et al. New Castle Upon Tyne: Cambridge Scholars, 20IO. $135^{-52}$. 